TecnoLógicas

ISSN-p 0123-7799

ISSN-e 2256-5337

Vol. 22, No. 44

Enero-abril de 2019

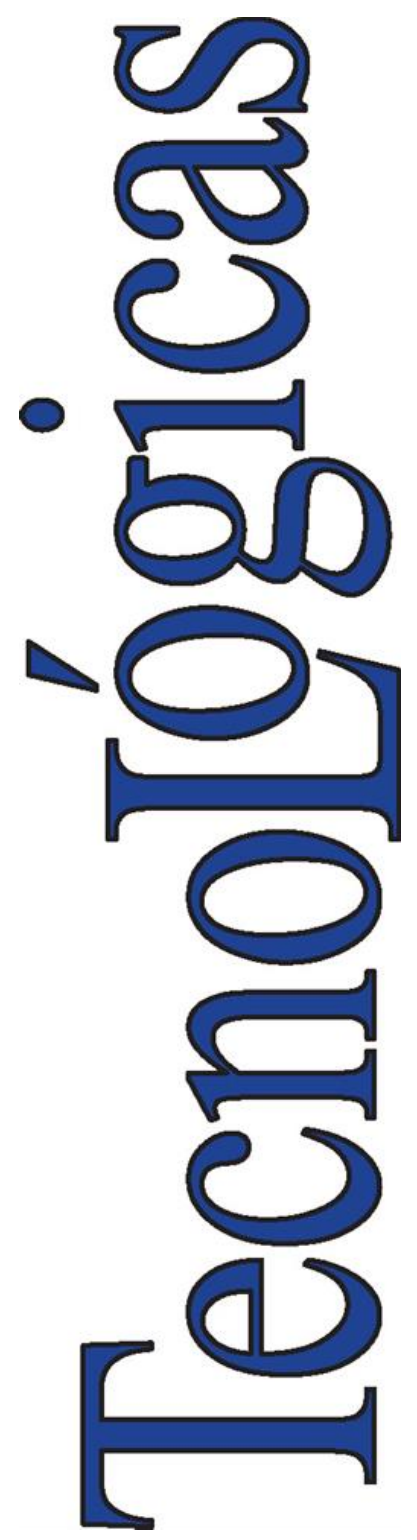

(C) Instituto Tecnológico Metropolitano Este trabajo está licenciado bajo una Licencia Internacional Creative Commons Atribución (CC BY-NC-SA)

\section{Evaluation of the phenol degradation capacity of microalgae-bacteria consortia from the bay of Cartagena, Colombia}

\section{Evaluación de la capacidad de degradación de fenol por consorcios bacteria-microalga aislados de la bahía de Cartagena, Colombia}

\author{
Daniela Alejandra Mora-Salguero ${ }^{1}$, Martha Josefina Vives \\ Florez ${ }^{2}$, Johanna Husserl Orjuela ${ }^{3}$, Miguel Fernández- \\ Niño ${ }^{4}$, y Andrés Fernando González Barrios ${ }^{5}$
}

Recibido: 07 de junio de 2018

Aceptado: 08 de noviembre de 2018

Cómo citar / How to cite

D. A. Mora-Salguero, M. J. Vives-Florez, J. Husserl-Orjuela, M. Fernández-Niño y A. F. González-Barrios, Evaluation of the phenol degradation capacity of microalgae-bacteria consortia from the bay of Cartagena, Colombia. TecnoLógicas, vol. 22, no. 44, pp. 149-158, 2019. https://doi.org/10.22430/22565337.1179

1 Bachelor of Chemical Engineer, Grupo de Diseño de Productos y Procesos (GDPP), Department of Chemical Engineering, Universidad de Los Andes, Bogotá-Colombia, da.mora1964@uniandes.edu.co

$2 \mathrm{PhD}$ in Science-Biology, Centro de Investigación en Microbiología (CIMIC), Universidad de Los Andes, Bogotá-Colombia, mvives@uniandes.edu.co

$3 \mathrm{PhD}$ in Environmental Engineering, Centro de Investigaciones en Ingeniería Ambiental (CIIA), Civil and Environmental Engineering, Universidad de Los Andes, Bogotá-Colombia, jhusserl@uniandes.edu.co

$4 \quad \mathrm{PhD}$ in Biochemical Engineering, Grupo de Diseño de Productos y Procesos (GDPP), Department of Chemical Engineering, Universidad de Los Andes, Bogotá-Colombia, ma.fernandezn@uniandes.edu.co

$5 \mathrm{PhD}$ in Chemical Engineering, Grupo de Diseño de Productos y Procesos (GDPP), Department of Chemical Engineering, Universidad de Los Andes, Bogotá-Colombia, andgonza@uniandes.edu.co 


\section{Abstract}

The development of new technologies for environmental reparation has allowed the application of inexpensive alternatives such as bioremediation, which has a high potential to treat ecosystems polluted with hydrocarbons. Microalgae-bacteria consortia have been identified as an efficient alternative for the detoxification of organic and inorganic contaminants and the removal of toxic compounds. This work investigates the phenol degradation potential of several alga-microbial consortia, which involved the algae Chlamydomonas reinhardtii and an osmotolerant phenol-resistant bacterial strain isolated from the bay of Cartagena, Colombia. A total of three bacterial strains were tested (i.e. Stenotrophomonas maltophilia, Microbacterium paraoxydans and Paenibacillus lactis) individually and in consortium with $C$. reinhardtii. Our data indicate a significant increase in the growth rate and a reduction in the lag phase of microorganisms in the consortium as compared to microorganisms growing in isolation. Interestingly, the inoculum ratio 2:1 (bacteria-microalgae) was shown to be the most robust taking into account that both microorganisms improved their growth. Afterward, the phenol degradation capacity of pure cultures and consortia in the presence of different phenol concentrations was evaluated. Our results reveal that such consortia perform better at low phenol concentrations; more specifically, the consortium Microbacterium paraoxydans-Chlamydomonas reinhardtii was the most effective: it reached a $49.89 \%$ phenol removal.

\section{Keywords}

Bioremediation, microalgae-bacteria, consortium, phenol degradation, hydrocarbons.

\section{Resumen}

El desarrollo de nuevas tecnologías de remediación ambiental ha permitido la aplicación de alternativas económicas como la bioremediación, que poseen un alto potencial para tratar ecosistemas contaminados con hidrocarburos. El consorcio microalga-bacteria se ha sido identificado como una eficiente alternativa para la detoxificación de contaminantes orgánicos e inorgánicos y la remoción de diversos compuestos tóxicos. En este trabajo, hemos investigado el potencial de degradación de fenol de varios consorcios microalga-bacteria, donde cada uno involucra un alga (i.e. Chlamydomonas reinhardtii) y una cepa bacteriana osmotolerante resistente al fenol, aislada de la bahía de Cartagena, Colombia. Un total de tres cepas bacterianas fueron evaluadas (i.e. Stenotrophomonas maltophilia, Microbacterium paraoxydans and Paenibacillus lactis) individualmente y en consorcio con C. reinhardtii. Nuestros resultados muestran un incremento significativo en la tasa de crecimiento y una reducción en la fase de latencia para los microorganismos creciendo en consorcio, en comparación con los microorganismos creciendo individualmente. Interesantemente, el inóculo con proporción 2:1 (bacteria-microalga) mostró una alta robustez, basados en el hecho que ambos microorganismos mejoraron su crecimiento. EL potencial de degradación de fenol fue evaluado para cultivos puros y consorcios demostrando una mayor actividad a bajas concentraciones de fenol, en donde el consorcio Microbacterium paraoxydans- Chlamydomonas reinhardtii demostró ser el más efectivo con un porcentaje de $49.89 \%$ de remoción de fenol.

\section{Palabras clave}

Bioremediación, microalga-bacteria, consorcios, degradación de fenol, hidrocarburos. 


\section{INTRODUCTION}

At the beginning of this century, fossil fuels accounted for approximately $80 \%$ of the global energy aimed at satisfying the world's energy consumption. Subsequently, inappropriate handling of these materials and their waste has created a serious problem worldwide due to the pollution of the soil and water with crude oil and byproducts [1].

A wide variety of environments could be contaminated with hydrocarbons. When the pollution occurs in soil, the hydrocarbons prevent gas exchange with the atmosphere, causing physicochemical changes like abnormal evaporation and penetration [2].

These compounds drastically change the conditions of salinity, causing the destruction of the tertiary structure of proteins, denaturation of enzymes, and dehydration of the cell, which is lethal to many organisms [2]. When the contamination occurs in water, a layer is generated by oil spills given the difference in density and thus preventing the entry of light and the gas exchange. Water-soluble compounds mix with water, which directly affects niches and ecosystems [2].

Due to the high toxicity of phenolic compounds, the Environmental Protection Agency of the United States and the European Union list them as dangerous pollutants [3]. The presence of phenols in the environment is an important risk for the aquatic biota, even at low concentrations [4].

Given the aforementioned problems, it is necessary to establish and develop technologies for environmental remediation. Most toxic compounds can be removed from environmental and industrial effluents by means of physicochemical methods; ozonation, activated carbon adsorption, chemical oxidation, Fenton's reagent, UV, and hydrogen peroxide are some of them [2].
The disadvantages of these treatments include their complexity, costs, and the fact that they can produce equally dangerous byproducts [4]. For these reasons, exploring the biodiversity to find a solution became relevant, and bioremediation appears to be an interesting alternative. It involves the use of some species that, given their metabolic characteristics, can act in multiple environments neutralizing toxic substances or making them harmless for the environment or human health [2].

A wide variety of microorganisms have a huge biotechnological potential to treat polluted wastewater and soil [5]. Specifically, consortia of bacteria and microalgae have proven to be more efficient in the detoxification of organic and inorganic pollutants, as well as the removal of nutrients from wastewater, than the individual microorganisms [5]. Microalgal photosynthesis provides oxygen, a key electron acceptor to the pollutant-degrading heterotrophic bacteria. In turn, bacteria support the photoautotrophic growth of their partners by providing carbon dioxide and other stimulatory means for continuing the photosynthetic cycle [6].

Interactions between autotrophic algae and heterotrophic bacteria can be cooperative or competitive. Certain bacteria are often accompanied by microalgae, even under the laboratory conditions of unialgal cultures [6]. This close contact between aerobic bacteria and microalgae has been reported between Chlorella sp. and Pseudomonas sp. [6], and between Chlorella sp. and Stenotrophomonas maltophilia [7]. The stimulatory growth of both microorganisms has been observed in such consortia; furthermore, several compounds produced by the microalgae can support a faster better growth of the bacteria [6]. Microalgae produce sheaths (of trilaminar organization) which consist of carbohydrate, protein, and metal cations 
that are related to the formation of algal cell aggregation, in which bacteria are associated by indirect adhesion as bacterial symbionts on the sheath and by direct adhesion over the algal cell surface., As a result, the diffusion distance may be reduced, and rapid and efficient exchange of substrates is allowed [6]. Improved algal growth has been reported in the coinoculation of bacterial strains (isolated from long-term laboratory algal cultures) than in algae alone [6], which suggests that the exchange of compounds between these microorganisms might improve their growth. Proximity, chemotaxis, adhesion, and mobility are important for the association microalgae-bacteria. Several reports have shown that aerobic heterotrophic organisms can use carbon compounds produced photosynthetically [7]. Photosynthesis, which is a reversible set of reactions, is inhibited by excessive dissolved oxygen; the oxygen consumption of bacteria decreases the tension in the microenvironment of algal cells, leading to more favorable conditions for algal growth [6]. Moreover, microalgae can use the carbon dioxide produced by bacterial mineralization for their in the photosynthesis.

To ensure the physical proximity between the microalgae and bacteria, both microorganisms need to be immobilized in a transparent matrix that must meet three requirements: (1) allow the entry of light needed by the microalgae to carry out their photosynthetic processes; (2) be small enough to allow diffusion of oxygen and nutrients; and (3) be large and heavy enough to prevent buoyancy and assure complete immersion in the growth medium [8]-[9].

Some reports of phenol bioremediation have evaluated concentrations between 250 and $500 \mathrm{ppm}$ in the treatment system that were reduced to less than $5 \mathrm{ppm}$ in some bacterial communities [10]. In the same way, Chlamydomonas reinhardtii and Chlorella vulgaris Beyerinck have demonstrated potential for utilizing phenol as a carbon source in an agar salt medium [11]. Another report introduced the ability of Stenotrophomonas species to degrade organophosphates and phenol simultaneously; they found a relation between the concentration of phenol and the optical density of the culture [12]. Likewise, a different study examined the biodegradation of phenol in a batch culture by pure strains of Paenibacillus sp; they screened several concentrations of phenol (from $100 \mathrm{ppm}$ to $600 \mathrm{ppm}$ ) on a mineral salt agar medium and observed a $53.86 \%$ degradation of phenol at $500 \mathrm{ppm}$ [13].

This work evaluates the phenol degradation capacity of microalgaebacteria consortia using three bacterial strains isolated from the bay of Cartagena, Colombia, and the microalga Chlamydomonas reinhardtii. Thus, this work will contribute to biotechnology studies on bioremediation using Colombian native bacterial strains.

\section{MATERIALS AND METHODS}

\subsection{Microorganisms and media}

Strains were isolated in a mineral medium with phenol (ATCC, USA) as their only source of carbon and energy; they were also identified by $16 \mathrm{~S}$ rDNA gene, using the primers 1492r (5'-TACCTTG TTACGACTT) and 27F (5'AGAGTTTGATCMTGGCTCAG) as previously described [9]. The company Genewiz (South Plainfield, NJ) conducted the sequencing of the PCR products. Isolates were identified as Stenotrophomonas spp. (C2), Microbacterium spp. (C7A), and Paenibacillus spp. (C7B), with 99\% identity to Stenotrophomonas maltophilia strain KW 98 16S ribosomal RNA gene (Accession number JX262398.1), 99\% 
identity to Microbacterium spp. BAB-4119 16S ribosomal RNA gene, (Accession number KJ778662.1), and 99\% identity to Paenibacillus lactis strain NASCB-5 16S ribosomal RNA gene (Accession number KP100165.1), respectively.

A Tris-Acetate-Phosphate (TAP) medium (Culture Collection of Cryophilic Algae, 2014) was used for all the cultures: pure cultures and consortia as well as pure cultures and consortia with added phenol. Said medium contained a phosphate solution $\quad 1 \mathrm{ml} \quad\left(\mathrm{K}_{2} \mathrm{HPO}_{4} \quad 28.8 \mathrm{~g} \quad 100 \mathrm{ml}^{-1}\right.$, $\left.\mathrm{KH}_{2} \mathrm{PO}_{4} 14.4 \mathrm{~g} 100 \mathrm{ml}^{-1}\right)$, salts $25 \mathrm{ml}\left(\mathrm{NH}_{4} \mathrm{Cl}\right.$ $15 \mathrm{~g} \mathrm{~L}^{-1}, \mathrm{MgSO}_{4} 7 \mathrm{H}_{2} \mathrm{O} 4 \mathrm{~g} \mathrm{~L}^{-1}, \mathrm{CaCl}_{2} 2 \mathrm{H}_{2} \mathrm{O}$ $\left.2 \mathrm{~g} \mathrm{~L}^{-1}\right)$, trace elements $1 \mathrm{ml}\left(\mathrm{H}_{3} \mathrm{BO}_{3} 1.14 \mathrm{~g}\right.$ $100 \mathrm{ml}^{-1}, \mathrm{ZnSO}_{4} 7 \mathrm{H}_{2} \mathrm{O} 2.2 \mathrm{~g} 100 \mathrm{ml}^{-1}, \mathrm{MnCl}_{2}$ $\begin{array}{llllll}4 \mathrm{H}_{2} \mathrm{O} & 0.5 \mathrm{~g} & 100 \mathrm{ml}^{-1}, & \mathrm{FeSO}_{4} & 7 \mathrm{H}_{2} \mathrm{O} & 0.5 \mathrm{~g}\end{array}$ $100 \mathrm{ml}^{-1}, \mathrm{CoCl}_{2} 6 \mathrm{H}_{2} \mathrm{O}$ 0.16g $100 \mathrm{ml}^{-1}, \mathrm{CuSO}_{4}$ $5 \mathrm{H}_{2} \mathrm{O} \quad 0.16 \mathrm{~g} 100 \mathrm{ml}^{-1},\left(\mathrm{NH}_{4}\right) 6 \mathrm{Mo}^{-} \mathrm{O}_{24} 4 \mathrm{H}_{2} \mathrm{O}$ $0.11 \mathrm{~g} 100 \mathrm{ml}^{-1}$, EDTA $5 \mathrm{~g} 100 \mathrm{ml}^{-1}$ ), acetic acid $1 \mathrm{ml}$, and tris $2.42 \mathrm{~g}$. All the reagents were obtained from a local supplier (Sigma-Aldrich, USA).

\subsection{Growth monitoring and algae-bacteria ratio selection for the inoculum}

The growth rate was evaluated in order to select the best conditions for degradation. Subsequently, individual and consortium growth curves of cultures (growing in a $15-\mathrm{mL}$ TAP medium at $27^{\circ} \mathrm{C}$ and 100 RPM for 150 hours under continuous light) were obtained and compared to assess culture conditions. Optical density measurements were carried out at $620 \mathrm{~nm}$ for bacteria and 685 $\mathrm{nm}$ for microalgae in a UV-vis spectrophotometer (Agilent, CA, USA) to determine the growth rates for approximately 150 hours. The OD length used in the measurements was changed because of the maximum absorption wavelength of bacteria $(620 \mathrm{~nm})$ and microalgae (685 $\mathrm{nm})$.

Moreover, microalgae cells were counted using a Neubauer chamber.
Inoculum ratios of $1: 1,2: 1$ and $1: 2$ (for microalgae and bacteria, respectively) were evaluated. Here, 1 is equivalent to $100 \mu \mathrm{l}$ and 2 equals $200 \mu \mathrm{l}$ of inoculum. All cultures were monitored by light microscopy to analyze the interaction between the microalgae and the bacteria.

\subsection{Phenol degradation evaluation}

In order to evaluate the potential for phenol degradation of the consortia, an acclimation of the microorganisms to phenol at $50 \mathrm{ppm}, 100 \mathrm{ppm}$ and $150 \mathrm{ppm}$ of phenol concentration was induced. TAP medium was added to all cultures containing different phenol concentrations. Their potential to degrade phenol was evaluated at 48 and 96 hours of incubation at $27^{\circ} \mathrm{C}$ with light by liquid chromatography (Agilent 1260 Infinity HPLC) using a ZORBAX Eclipse Plus C18 HPLC column under several conditions: injection volumes from 0.1 to $100 \mu \mathrm{l}$; column length up to $300 \mathrm{~mm}$ and internal diameter $0.05-8 \mathrm{~mm}$; temperature range from $10^{\circ} \mathrm{C}$ below ambient to $80^{\circ} \mathrm{C}$; maximum pressure 600 bar; and flow rate range from 0.05 to $5 \mathrm{~mL} / \mathrm{min}$ at 600 bar and 5 to $10 \mathrm{~mL} / \mathrm{min}$ at 200 bar. Multiple $1.5-\mathrm{ml}$ samples of the pure and mixed cultures media were filtrated and then transferred to a vial for chromatography. The percentage of degradation was calculated by comparing the peak areas of the degraded and control samples.

\section{RESULTS}

Since the growth of Chlamydomonas reinhardtii is facilitated by saline media and adequate media formulation is important for consortia development, the performance of the microalgae was evaluated when growing in the presence of potentially halotolerant organisms and phenol degrading strains isolated from 
national ecosystems characterized by high salt concentrations, such as the bay of Cartagena in Colombia. Therefore, a TAP medium was selected for the analysis of the consortia.

First, the behavior of each bacterial strain and microalga was individually analyzed. In general, bacterial strains and Chlamydomonas reinhardtii displayed growth after 4 days of incubation at $30^{\circ} \mathrm{C}$ and after 6 days of incubation at $27^{\circ}$. The behavior of microalgae and bacterial strains was found to be similar as the lag phase for all strains was around 50 hours (Fig. 1), which may indicate that the selected medium is appropriate for consortia growth.
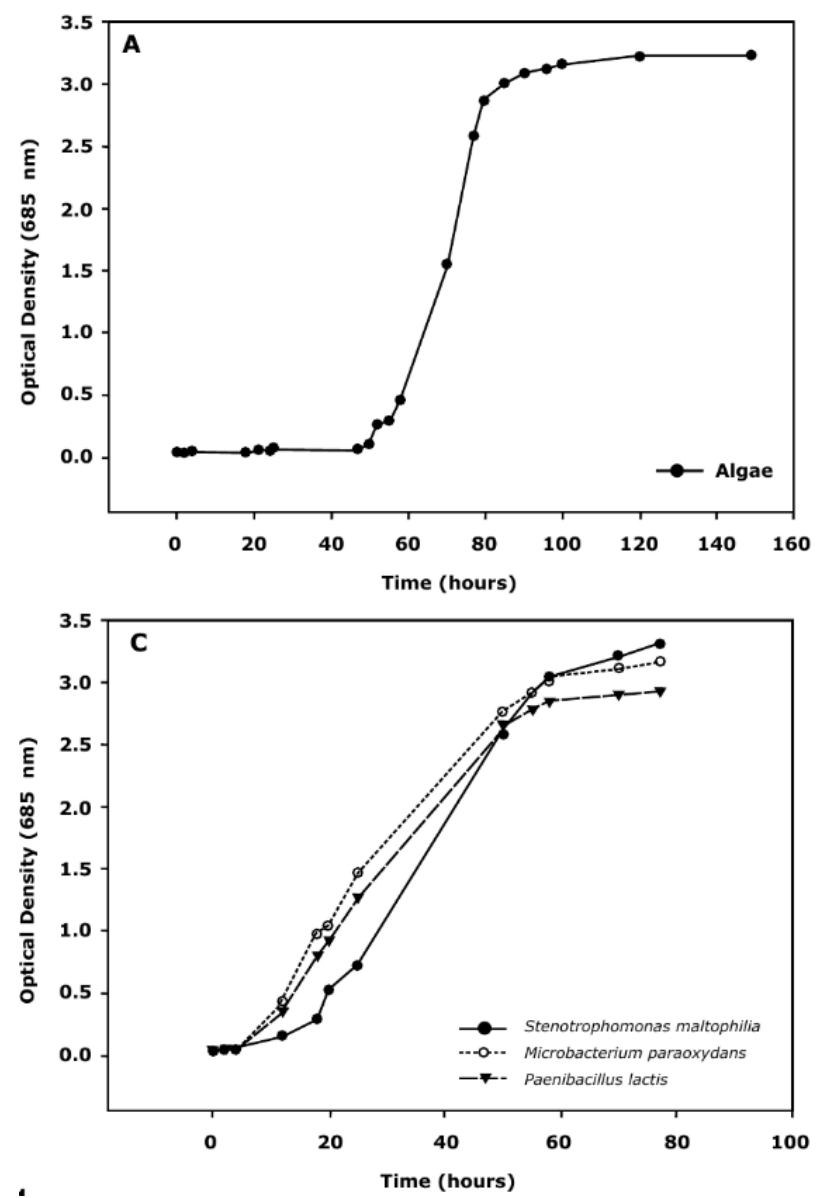

Moreover, the lag phase found in all the cultures is typical when phenol degradation is taking place, as the time for adaptation is remarkably longer than when different energy or carbon sources are available. This finding can improve the removal efficiency when the technology is scaled up, because a better strategy to acclimate each strain to phenol can be established. In addition, a reduction in the exponential phase of bacterial strains (compared to microalgae) was also found, possibly indicating a faster depletion and better adaptation of bacterial strains.

Light microscopy evaluations allowed to determine the presence of potential symbiosis in the consortia (Fig. 2 and Fig. $3)$.
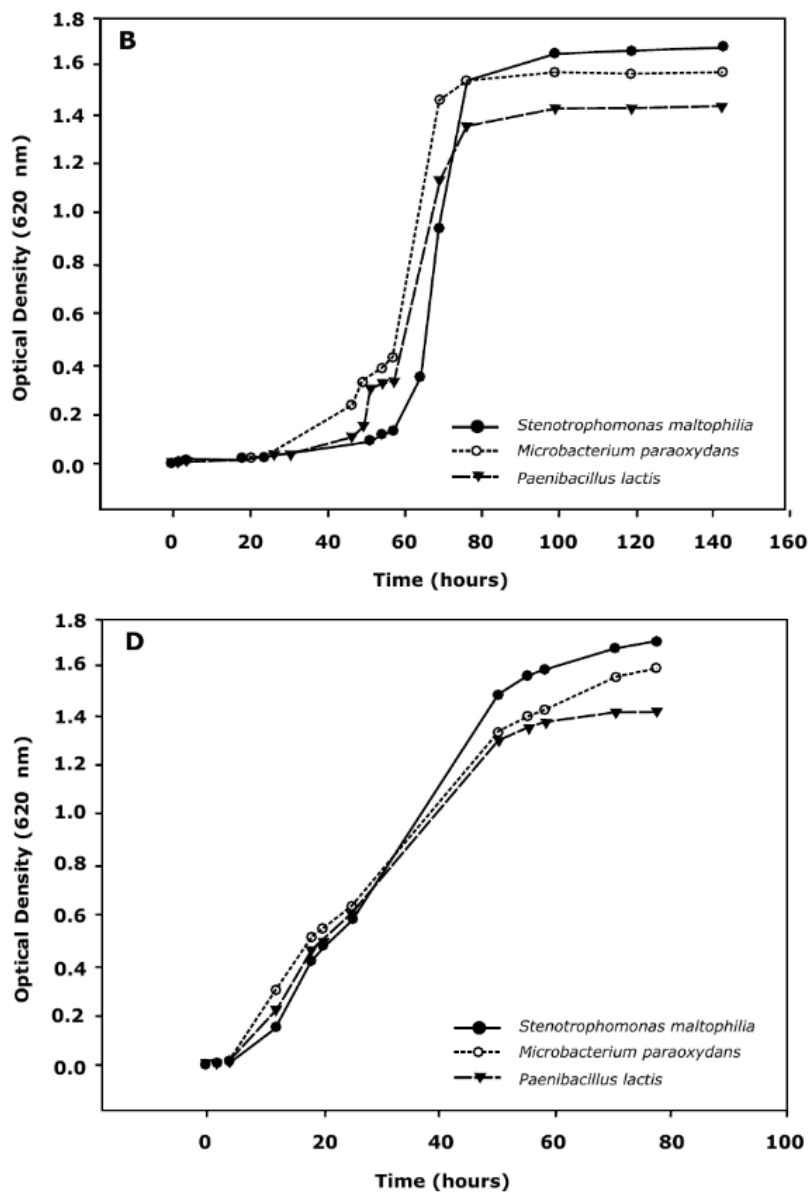

Fig. 1. Growth curves in a TAP medium. (A) Pure culture of microalgae Chlamydomonas reinhardtii, (B)

Pure cultures of bacterial strains, (C) Microalgae Chlamydomonas reinhardtii-bacteria consortia in a ratio of 1:2 (bacteria-microalgae), (D) Microalgae Chlamydomonas reinhardtii-bacteria consortia in a ratio of 2:1 (bacteriamicroalgae). Source: Authors' own work.. 


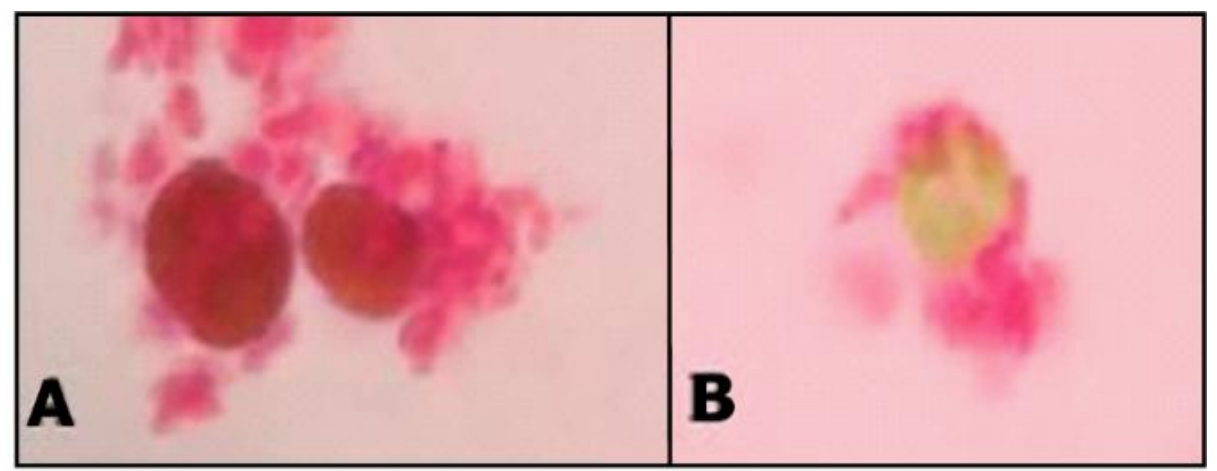

Fig. 2. Optical microscopy x100 of the consortium C7A-microalgae, fuchsine stained samples.

(A) Pre-inoculum ratio, 2:1. (B) Pre-inoculum ratio, 1:1. Source: Authors' own work.

In all cases a contact between the microalgae and the bacteria was detected, possibly indicating the interaction between them. Nevertheless, the 2:1 ratio displayed greater and more cellular aggregations in the cultures as well as more contact between the species (Fig. 2). As a result, the growth curves of the $2: 1$ ratio were obtained and faster growth of the consortia, compared to individual cultures, was found. This behavior was reflected in a shorter lag phase (down to $10 \mathrm{~h}$, an $80 \%$ reduction) and in half the time elapsed to reach the stationary phase (compared to individual cultures).

An initial visual comparison of the growth of different bacterial strains revealed interesting differences between them. It seems that the agglomeration of Microbacterium spp-microalgae is clearer than other strains. Moreover, the morphology of the algae does not seem to be affected by the bacterial strain present in the culture. The number of algal cells calculated in the $2: 1$ ratio culture $\left(3.09^{*} 10^{7}\right.$ cells $/ \mathrm{mL}$ ) also displayed a significant difference compared with its counterpart in the pure microalgae culture $\left(1.35^{*} 10^{7}\right.$ cells $/ \mathrm{mL}$ in average). Growth curves were also obtained for each strain in TAP medium (Fig. 1). Our data suggested that the growth rates of the microalgae and the bacterial strains are independent of the consortia, possibly indicating that several factors such as metabolism associated with the species or growth rate do not significantly affect the evolution of symbiosis.

Phenol degradation was then evaluated at different phenol concentrations (50, 100, and $150 \mathrm{ppm}$ ) by measuring phenol at 48 and $96 \mathrm{~h}$ in different inoculum ratios for each bacterial strain (Fig. 4), in pure cultures as well as consortia. The initial concentration of phenol presents a significant effect on phenol removal, as 50 ppm of phenol results in the most significant removal by the Microbacterium spp- $C$. reinhardtii consortia; nevertheless, this effect seems to be mediated by the specific bacterial strain because phenol removal by Paenibacillus spp. is negatively affected by the presence of $C$. reinhardtii. Finally, our data shows that the phenol removal capacity of Stenotrophomonas spp. is facilitated by the presence of the microalgae, but it does not reach the level of Microbacterium spp-C. reinhardti.

In general, it seems that high phenol concentrations negatively affect the synergy when microalgae are used; this was reflected in the fact that, in all the cases with 100 and $150 \mathrm{ppm}$, the phenol removal capacity of pure cultures is the same or higher than that of their consortia counterparts. Regarding the algae-bacteria ratio, our results confirm what was established without the presence of phenol, because the 2:1 bacteria-microalgae ratio displayed the most interesting removal capacity, especially the consortium Microbacterium spp-C. reinhardtii. 


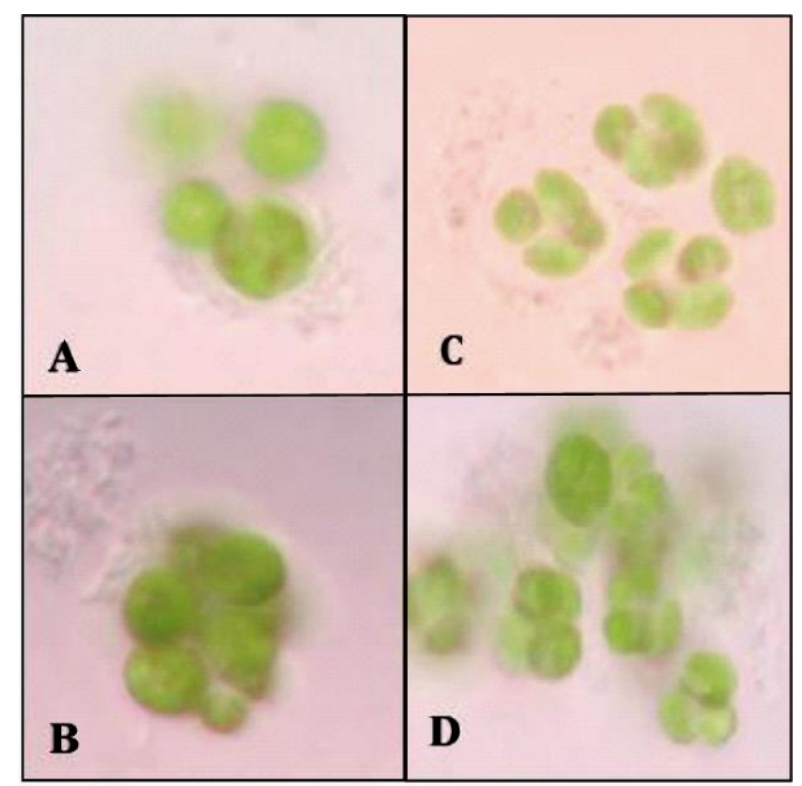

Fig. 3. Optical microscopy $\mathrm{x} 100$ of the consortia in a ratio of 2:1 (bacteria-microalgae). (A) Consortium C2microalgae. (B) Consortium C7B-microaglae. (C) and (D) Consortium C7A-microalgae.

Source: Authors' own work.

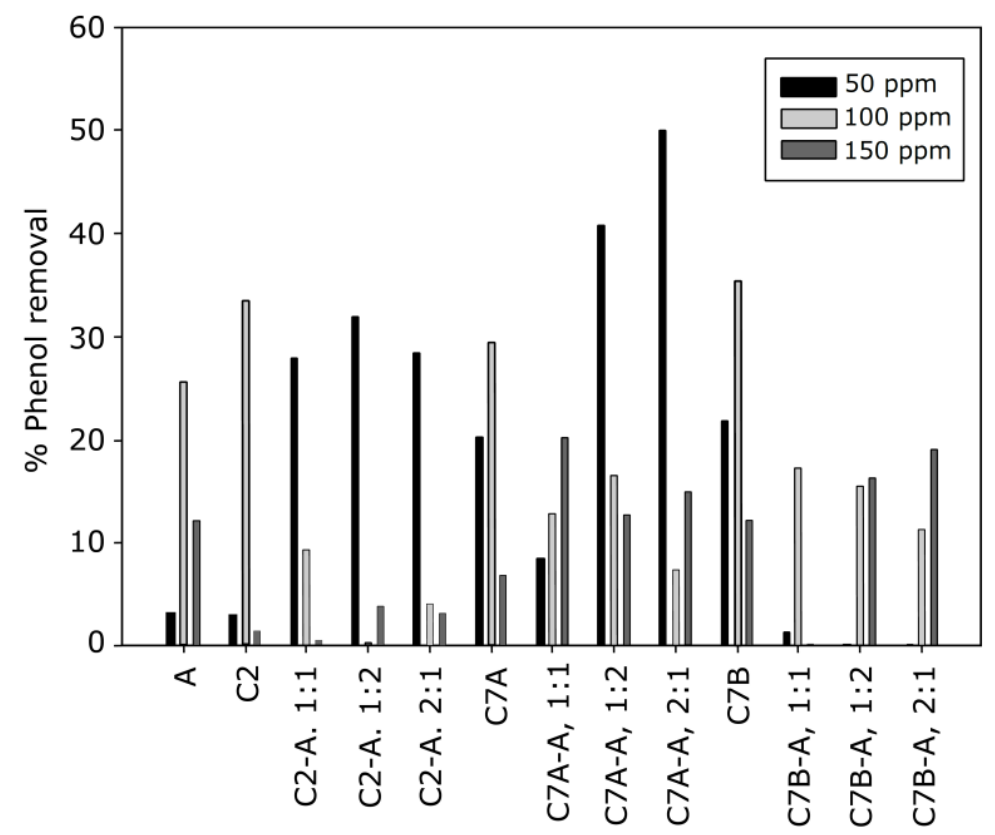

Fig. 4. Percentages of phenol removal in each culture at the evaluated concentrations. Abbreviations: A, microalga Chlamydomonas reinhardtii; 2 2, Stenotrophomonas maltophilia; C7A, Microbacterium paraoxydans; C7B, Paenibacillus lactis. 1:1, 1:2, and 2:1 denote the inoculum ratios of the consortia. Source: Authors' own work.

Phenol removal was finally evaluated using a modified TAP medium (without acetic acid and $100 \mathrm{ppm}$ of phenol as the only source of carbon). None of the bacterial species displayed growth; nevertheless, the microalgae did grow in this medium and the culture coloration was less green than in a regular medium. After the first measurement, it was clear that the microalgae are the microorganism 
Evaluation of the phenol degradation capacity of microalgae-bacteria consortia from the bay of Cartagena, Colombia

that leads the process of pollutant degradation.

\section{DISCUSSION}

First, our data suggest that the growth of the bacteria and microalgae under study was favored. A much faster growth was found in the consortia compared to pure cultures, which enables to claim that consortia enable growth stimulation. Furthermore, light microscopy revealed cell aggregations due to the tight contact between the microalgae and the different bacterial species, which may suggest symbiosis. Our results indicate that the formation of cell aggregations occurs as a result of the activation of defense mechanisms given the presence of other microorganisms in the same medium. Previous studies on associations of microalgae and bacteria have shown smaller cell aggregations in axenic cultures (only one species) than in their xenic counterparts (various species-consortia) and that cell formation (called floccules) takes place due to the growth stimulation that generates the interaction between different microorganisms [14].

Regarding the phenol degradation potential, the consortia created in this work present a better performance at low concentrations of the pollutant, which is one of the current bottlenecks in phenol remediation technologies [1]. The results of phenol degradation and microscopy enable to establish that a pre-inoculum ratio of $2: 1$ (bacteria-microalgae) is the most appropriate for the development of the consortia. Likewise, the most efficient consortium, in terms of phenol removal at $50 \mathrm{pmm}$, is developed with the strain Microbacterium spp, which achieved a removal percentage of approximately 50\% (Fig. 4); this may indicate that 100 and 150 ppm concentrations induce resistance mechanisms instead of biodegradation metabolism.

The interactions between microalgae and bacteria are complex, including competition for resources and the production of extracellular polymeric substances and exudates [15]. Furthermore, bacteria tend to be effective competitors for resources because they have a rapid growth rate, a greater volume ratio per surface area and rapid rates of nutrient intake [15]. Some studies report competitive interactions where the inhibition of bacterial growth (Vibrio alginolyticus) is observed in alga cultures (Skletonema costatum) as a result of competitive exclusion [16]. Therefore, the dynamics of interaction between populations should be taken into account to create mixed cultures. The growth of the consortia observed in this work may indicate a symbiotic relationship between the species due to the cellular aggregations. Nevertheless, such aggregations may also be caused by resistance mechanisms activated by the microalgae.

\section{CONCLUSIONS}

Our results suggest that both growth rate and lag phase are different between microorganism growing alone or in consortium. Interestingly, the inoculum ratio 2:1 (bacteria-microalgae) was shown to be the most robust considering that both microorganisms improved their growth. In addition, our data revealed the highly potential of using bacteria-microalgae consortia for phenol degradation, where consortia displayed a better performance at low phenol concentrations. The data presented in this work may be relevant for the bioremediation of environments polluted with hydrocarbons, and it offers the advantage of using native Colombian bacterial strains. 


\section{CONFLICT OF INTERESTS}

This research was conducted in the absence of any commercial or financial relationships that could be construed as a potential conflict of interest.

\section{ACKNOWLEDGEMENTS}

We thank Universidad de Los Andes for the financial support and the researchers at Grupo de Diseño de Productos y Procesos (GDPP) for their constant contributions and correct observations.

\section{REFERENCES}

[1] D. Wolicka, A. Suszek, A. Borkowski, and A. Bielecka, "Application of aerobic microorganisms in bioremediation in situ of soil contaminated by petroleum products," Bioresour. Technol., vol. 100, no. 13, pp. 3221-3227, Jul. 2009.

[2] A. Martínez-prado, M. E. Pérez-López, J. Pinto-Espinoza, B. A. Gurrola-Narváez, and A. L. Osorio-rodríguez, Biorremediación de suelo contaminado con hidrocarburos empleando lodos residuales como fuente alterna de nutrientes, vol. 27, no. 3. Centro de Ciencias de la Atmósfera, UNAM, 2011.

[3] P.-P. Zhang, Z.-G. Shi, and Y.-Q. Feng, "Determination of phenols in environmental water samples by two-step liquid-phase microextraction coupled with high performance liquid chromatography," Talanta, vol. 85, no. 5, pp. 2581-2586, Oct. 2011.

[4] K. Lika and I. A. Papadakis, "Modeling the biodegradation of phenolic compounds by microalgae," J. Sea Res., vol. 62, no. 2-3, pp. 135-146, 2009.

[5] M. T. Madigan, R. Guerrero, M. C. Chica Rueda, R. Duro, M. Piqueras, and C. Barrachina, Brock biología de los microorganismos, 10th ed. Pearson Educación, 2015.

[6] S. R. Subashchandrabose, B. Ramakrishnan, M. Megharaj, K. Venkateswarlu, and R. Naidu, cyanobacteria/microalgae and bacteria: Biotechnological potential," Biotechnol. Adv., vol. 29, no. 6, pp. 896-907, Nov. 2011.

[7] D. J. R. Maria Filomena, And, and S. C. D. M. Rui Manuel, "Chlorella vulgaris as Soil Amendment: Influence of Encapsulation and Enrichment with Rhizobacteria," Int. J. Agric. Biol., vol. 13, no. 5, p. 6, 2011.

[8] L. E. DeBashan and Y. Bashan, "Bionota. Bacterias promotoras de crecimiento de microalgas: una nueva aproximación en el tratamiento de aguas residuales," Rev. Colomb. Biotecnol., vol. 5, no. 2, pp. 85-90, 2003.

[9] J. A. Frank, C. I. Reich, S. Sharma, J. S. Weisbaum, B. A. Wilson, and G. J. Olsen, "Critical Evaluation of Two Primers Commonly Used for Amplification of Bacterial 16S rRNA Genes," Appl. Environ. Microbiol., vol. 74, no. 8, pp. 2461-2470, Apr. 2008.

[10] A. S. Whiteley and M. J. Bailey, "Bacterial community structure and physiological state within an industrial phenol bioremediation system," Appl. Environ. Microbiol., vol. 66, no. 6, pp. 2400-2407, Jun. 2000.

[11] D. Samanthakamani and N. Thangaraju, "Potential of freshwater microalgae for degradation of phenol," Indian J. Sci. Res. Technol., vol. 3, no. 2, pp. 9-12, 2015.

[12] Z. Liu, C. Yang, H. Jiang, A. Mulchandani, W. Chen, and C. Qiao, "Simultaneous Degradation of Organophosphates and 4Substituted Phenols by Stenotrophomonas Species LZ-1 with Surface-Displayed Organophosphorus Hydrolase," J. Agric. Food Chem., vol. 57, no. 14, pp. 6171-6177, Jul. 2009.

[13] J. Lee, D.-H. Cho, R. Ramanan, B.-H. Kim, H.-M. Oh, and H.-S. Kim, "Microalgaeassociated bacteria play a key role in the flocculation of Chlorella vulgaris," Bioresour. Technol., vol. 131, pp. 195-201, Mar. 2013.

[14] M. Rivas and C. Riquelme, "Probiotic Biofilms," in Probiotics, InTech, 2012.

[15] F. M. I. Natrah, P. Bossier, P. Sorgeloos, F. M. Yusoff, and T. Defoirdt, "Significance of microalgal-bacterial interactions for aquaculture," Rev. Aquac., vol. 6, no. 1, pp. 48-61, Mar. 2014.

[16] M. L. Shuler and F. Kargi, Bioprocess Engineering Basics concepts, 2nd ed. Prentice Hall, 2001. 